\title{
BLOGS AND BUSINESS: OPPORTUNITIES AND HEADACHES
}

\author{
Wallace Wood, Bryant University, wwood@bryant.edu \\ Robert Behling, Arrowrock Technologies, rbehling@ hotmail \\ Susan Haugen, University of Wisconsin - Eau Claire, shaugen@uwec.edu
}

\begin{abstract}
Web logs, commonly called blogs were originally developed and used by individuals. This paper focuses on blogs from the point of view of businesses. Current professional literature on blogging was examined to determine how blogs are being used, who uses them, and what are their advantages/disadvantages. A survey of full time working students in southern New England was conducted to collect primary data on the corporate use of blogs to compare with the result of the literature search.
\end{abstract}

Keywords: Corporate Blogs, Corporate Blogging

\section{INTRODUCTION}

The term blogging is derived from Web Log, an online diary where individuals post thoughts and ideas, daily events, and their personal knowledge about specific topics. Through comments, linking and trackback, bloggers share their knowledge with each other and develop and refine new ideas. Blogs were first introduced as a way to share personal journals. In addition to personal journals, there are now business blogs being used to promote products and services, publish company and other news, and provide customers with technical support [21]. In recent years blogs have gone from simple online diaries to must read Internet publications that rival the reach and influence of traditional media [7]. It has been said that blogs can serve as the canary in the coal mine for company image problems, as well as understanding customer concerns and responding to their needs [10].

Blogging is transforming the way the Internet is used by allowing individuals and businesses to communicate directly with other individuals, employees, and customers, while fostering an open exchange of ideas. In addition to commentary, blogs can also be linked to other blogs or employ a search engine utility [7]. Blogging has become a significant part of the online culture. Surveys conducted in 2004 found that $27 \%$ to $30 \%$ of U.S. Internet users were blog readers and $12 \%$ of U.S. Internet users had posted comments or other material on blogs $[4,18]$.
Since blogs were first introduced, they have become much more than personal journals. Once individuals and organizations found that they can publish almost anything they want, virtually for free, blogging has become a simple method of creating a Web presence. Add to that an ability to search and retrieve information that has been input to the blogs, and you have the makings of a usable business tool. Blogging offers companies who use it a new way to keep their various constituencies up to date on important developments and trends and provides a practical and easy way to share knowledge, get feedback and engage readers. Also, blogs are interactive and cheap to deploy, presenting an attractive form of business communication [2].

\section{Types of Business Blogs}

Businesses can develop external (outwardly facing) corporate blogs to interact with customers and the public. Microsoft has used blogs to promote Longhorn Beta 1, its next generation Windows release [16]. Cisco Systems uses blogs to present new information on specific company topics [1]. Other firms such as Intuit have product managers post updates and public plans, and engage in dialog with their customers, and yogurt maker Stonyfield Farm uses blogs to build loyalty and address customer comments and concerns [3].

Internal (inwardly facing) blogs give employees the opportunity to write about a range of issues, from personal experiences to thoughts and concerns about the company and as such are another form of internal communication, except that like message boards, they possess the potential for anonymity and its resultant problems [11]. An internal blog might be used to express an employee's ideas about corporate policies and procedures. Also, firms have used internal blogs to post research information from engineering studies of product failures, something like a lessons learned posting, to help employees avoid similar problems in the future. Businesses can also support internally written blogs to help capture and share corporate knowledge. General Motors uses blogs to steer past its own PR department and communicate with their stakeholders [21]. Blogs can also be used to facilitate knowledge management and 
collaboration, enabling faster business decisions, opportunities for innovation, and cost savings [22]. Companies often like to use blogs because they have an informal, conversational tone that is more palatable than traditional business communications or published materials.

Small businesses can benefit from blogs as it gives them a Web presence that they may not be able to afford through traditional channels. Procedures and vehicles for internal and customer communications may not be as refined as with large organizations, and budget restrictions may limit these communications through traditional means. Blogs give the look and feel of a newsletter, are useful for keeping customers and other interested people up to date on news that pertains to their business, and provides a friendly and somewhat casual interface to the company. For most visitors the level of sophistication does not seem to determine whether or not the blog is visited, it is whether or not the available information on the blog is relevant, honest and consistent.

It should be noted that blogs are not meant to be a substitute for the traditional company communications and PR activities of an organization; they serve to complement these activities [19]. A number of Internet services are available to establish a site for bloggers, including some of the more well known such as MSN Spaces, Google's Blogspot, Yahoo 360, Xanga.com and LiveJournal. There are many more available; these are just a few of the more popular ones.

\section{Advantages of Blogs}

Blogging presents many advantages to business organizations. The technology allows businesses to expand their audience without having to rely on traditional, and often inefficient, means of communicating with their customers [15]. Setting up a simple blog requires a minimum of effort or involvement from the IT Department, and can be done for a modest cost [20]. Once set up, blogs can be very effective in promoting products and services, which can help to reduce advertising and marketing costs [8]. Blogging allows for greater Web visibility and can gain search engine prominence, helping to direct Web traffic to the company Web site [19]. Often times blogs are ranked higher by search engines because the information is updated more frequently [9].

An effective organizational blog helps the organization to participate in business enhancing conversations to build relationships for both current and future customers, partners, and employees [19]. Blogs help an organization better understand the needs and wants of their customers, obtain feedback on products and services immediately, and in effect have customized and personalized market research. Blogs also provide organizations an opportunity to respond to criticism from the media and others who might be posting negative comments on other blogs [23].

\section{Organizational Concerns}

Because blogs are not without their discrepancies and challenges, organizations should address important issues before committing to a corporate blog. The first, and most important concern for any organization, is to determine if blogging fits the organization's business plan. To do this, the organization needs to clearly identify what they see as the business objectives of the blog. When objectives have been formalized and agreed upon by management, technology and software decisions need to be made: use a blog hosting service; install blog software on the server; or use blog software to publish pages to the server [20]. Once this decision is in place, personnel assignments can be made and content developed. Blogs are very writing intensive, and it is difficult to write ideas effectively. Organizations need to be aware that it is very challenging to write clearly, coherently and in an interesting manner for public viewing, and maintaining the blog can be time consuming [14]. Obsolete blogs and blogs that offer nothing of value to the reader quickly lose favor and therefore lose effectiveness.

Blogs present a substantial opportunity for the introduction of personal bias. They also provide a window to the weaknesses of individuals, especially with writing and expressing ideas. While blogging is an excellent way to connect with groups and individuals, it is also a risky venture if firm guidelines are not established. Clear and publicly posted rules governing the language and content for a company blog, and written policies for personal blogs linked to the company blog are essential. Bloggers making careless statements about the organization could see them used in litigation, and careless or untruthful statements about employees and individuals may jeopardize the organization to litigation for privacy infringement. Whatever technical approach is taken, there will be an investment in personnel, time and money [13]. Hutchins [11] suggests that company sponsored external blogs should be tightly controlled to avoid legal problems. 
Information security and confidentiality becomes a concern once the blog is operational. Blogging employees may disclose sensitive information about the company, present inside information in a negative way, or discredit the company by providing false or inaccurate information. Whether an accident or by design, the organization can be hurt by these activities. While these same risks and exposures are present with any employee/customer interface, such as reception or telemarketing, the risk of significant damage to the organization increases with blogging because a wider audience has opportunities to interact with the sensitive information. Examples include sharing insider information such as earnings expectations and taking on competitors and their products as an individual rather than as a company following approved policies and procedures. Because blog content is available for the company through the Internet to a world wide audience, blog management needs to be coordinated with the organization's information policy and records management programs. Also, it needs to be made clear whether the content of the blog is an individual's thoughts or company information. It is reasonable to expect that most bloggers do not have authority to speak for the organization, but to the casual reader, this may not be clear. Employee awareness and training, written and easy to understand blogging policies and guidelines, and regular blog monitoring will provide a first line of defense for the organization [17].

Another concern has to be the entries to the blog made by individuals outside the business. Because there is no monitoring, editing or verification of posted information, individuals can post anything they like, even false or malicious information. A customer could post that they had a terrible experience with a product, recommend that no one purchase the product, and even rant and rave about individuals in the company. Scandalous information can be easily published, added to with little effort, the text becomes a permanent record, and the blog then poses great risk to the reputation of the company [3]. A company maintaining a blog would be hard pressed to stop this kind of posting, and some might view a blog as a platform for individuals to lob bombs at their organization.

Individuals need to be aware that blogging creates a permanent record of thoughts and ideas, which may be a good or bad thing. For a chronic complainer, negative postings to a blog may come back to haunt them when they apply for another job, an internal transfer, or even during their annual review. Since blogging is a recent phenomenon for organizations, perhaps the most important disadvantage is a lack of precedents and guidelines for both individuals and organizations.

Organizations also need to be aware of their legal liabilities for unmoderated content presented on a blog. Blogs may put a company's assets, reputation and future at risk. Without strategic blog-related policies, rules and procedures, organizations face the potential for workplace lawsuits [6]. Paramount is the legal problem that the anonymity of remarks on the comments section of a corporate blog can have for the company [11] Cannondale Bicycle is approaching blogging cautiously, with trusted employee bloggers given direct posting privileges and other employee postings going through an edit process [2].

If the blog is to be an official record of the organization, then the organization must provide workable access, indexing tools, preservation, scheduling, storage and access for as long as needed for administrative, legal, research and other purposes [5]. Businesses need to be able to separate hype from reality in order to maintain some credibility with customers. People will not continue to read a blog if they determine it to be light on facts and heavy on marketing and advertising.

And finally, we cannot overlook the impact of blogs and blogging on people at work. It has been reported [12] that about one in four people in the U.S. labor force visits blogs, and spends an average of more than three hours per week, or about 40 minutes per day, engaged with non-work related blogs. Hard data is limited, so reports are based on estimates and extrapolation from reviews of blog related surveys. One source of data analyzed is blog server traffic patterns, rocketing up at 8:00 am, peaking at 5:00 pm, and fading downward until California workers head home. Blog server traffic on weekends is much lighter, supporting the viewing at work argument. This extrapolated data suggests that workers will waste about 2 million work years reading blogs unrelated to their job.

\section{RESEARCH METHODOLOGY}

A survey was designed to determine what kinds of companies, classified by both principal business activity and size, are providing blogs for either their customers or their employees.

The survey was administered to graduate students in a Master's of Business Administration program who were employed full-time in businesses and organizations in southern New England. After eliminating survey results for duplicate companies 
and deleting incomplete responses, the resultant sample size was 72 .

\section{SURVEY RESULTS AND DISCUSSION}

Table 1 provides the summarized results for the survey. The results for the sample are different than might be expected given the percentages cited by most industry observers in the current literature regarding blogs.

Table 1. Survey Results for 72 Companies/Organizations

\begin{tabular}{|l|c|c|c|}
\hline & Yes & No & Have Considered Blog? \\
\hline Number Providing Blog & 5 & 67 & 3 \\
\hline Percentage Providing Blog & $7 \%$ & $93 \%$ & $4 \%$ \\
\hline
\end{tabular}

Of the 5 companies in the survey providing blogs, three were large companies with over 10,000 employees. While this number of companies is too small to make any generalizations, these results are consistent with the literature review where many of the blogs cited were from large companies. It is also consistent with a survey reported in BusinessWeekOnline where only 22 of the 500 $(4.4 \%)$ largest U.S. companies operate official corporate blogs [2].

To the question of whether the respondents have personal blogs, 13 (or 18\%) replied yes, which is less than the $25 \%$ cited earlier. Twelve individuals (17\%) said they spend an average of 2.7 hours/week using business blogs and 16 individuals (22\%) reported spending an average of 3.4 hours/week using personal blogs. This later result is consistent with the data cited previously.

\section{CONCLUSIONS}

Everything in the literature indicates that blogging is gaining momentum and will be used by more and more companies and organizations. While this trend seems to be contradicted by the results of the survey of southern New England companies, it is perhaps too early to state that there is a contradiction, but the need for a follow up survey in the future seems warranted. Businesses are aware that blogging is a very inexpensive way to help them gain Internet and market presence, obtain consumer feedback and provide a forum for employees to share ideas. While blogs have their disadvantages, they also hold great potential for organizations. Creating an outlet for public discussion can enhance the reputation of the organization and provide a timely means for customers to interact with the company in an informal way and put a human face on company communications. To ensure blog content, procedures and policies are not in conflict with the organization, they should be reviewed by appropriate regulatory, legal and management staff. A serious downside of blogs is at-work time spent interacting with blogs that are unrelated to the job, costing companies millions of dollars in labor each year.

\section{REFERENCES}

1. Alexander, S. (2001). Order out of Chaos, Online Learning, Retrieved September 23, 2005 from: http://www.onlinelearningmag.com/onlinelearning/magazine /article_displayh.jsp?vnu_content_id=1224578.

2. Baker, S. (2006). The Inside Story on Company Blogs, Business Week, Retrieved February 21, 2006 from http://www.businessweek.com/print/technology/content/feb2006/tc20 060214_402499.htm

3. Baker, S. \& H. Green. (2005). Six Tips for Corporate Bloggers, BusinessWeek, Retrieved September 25, 2005 from: http://www.businessweek.com/magazine/content/05_18/b39331001_ mz001.htm.

4. Claburn, T. (2005). Blogs are Mainstream, Information Week, August 15, p. 20.

5. Dearstyne. B. (2005). BLOGS: The New Information Revolution? Information Management Journal, May, p. 38.

6. Flynn, N. (2005). Blog Rules, Optimize, Retrieved September 13, 2005 from: http://www.optimizemag.com/article/showArticl e.jhtml?articleID=56900718. 
7. Foley, J. (2002). Are You Blogging Yet? Information Week, July 22.

8. Foremski, T. (2005). IBM is Preparing to Launch a Massive Corporate Wide Blogging Initiative as it Seeks to Extend its Expertise Online, Retrieved from: http://www.siliconvalleywatcher.com/mt/archive s/2005/05can_blogging_bo.php

9. Goodwin, K. (2003). Putting B-Blog Into Action, Retrieved October 12, 2005 from: http://clickz.com/experts/ em_mkt/enl_strat/article.phd/1586851.

10. Heun, C. (2006). Catch The Blog Buzz, Information Week, Retrieved February 19, 2006 from http://www.informationweek.com/shared/printableArticle.jhtml?articleID $=178$ 601677

11. Hutchins, J. (2006). Corporate Blogging: Beyond the Water Cooler. ComputerWorld, Retrieved February 14, 2006 from http://www.computerworld.com/printthis/2005/0 ,4814,106135,00.html

12. Johnson, B. (2005). What Blogs Cost American Business, Retrieved October 25, 2005 from: http://adage.com/news.-cms?newsId=46494.

13. Masnick, M. \& P. Agarwalo. (2002). Enterprise Blogging, Retrieved September 8, 2005 from: http://www.techdirt.com/reports/dll/ebwhitepape r.pdf.

14. McGovern, G. (2004). Blogs \& Blogging: Advantages and Disadvantages, Retrieved September 12, 2005 from: http://www.corporateblogging.info/2004/08/web-content-guru-gerrymcgovern-on.asp-.
15. McMillan, R. (2004). HP Quietly Begins Weblog Experiment, Retrieved September 18, 2005 from: http://netw-lrkworld.com/news/2004/1123-hpquiet.- html.

16. Mook, N. (2005) MS Taps Bloggers to Promote Longhorn, BetaNews, Retrieved September 19, 2005 from: http://www.betanews.com/article/MS_Taps_Blo ggers_to_Promote_Longhorn/1115049500.

17. Piazza, P. (2005). Trouble in the Biosphere, Security, Management, Aug, p. 40.

18. Rainie, L. (2005). The State of Blogging, Retrieved September 19, 2005 from: http://www.pewinternet.org/pdfs/PIP_blogging_data.pdf.

19. Sessum, J. (2005). To Blog or not to Blog, Retrieved September 8, 2005, from http://www.thecontenfactor.com/ landing/200508/.

20. Teten, D. \& S. Allen. (2005). Blogging to Build Business Relationships, Retrieved September 19, 2005 from: http://axentra.net/www/ scottallen/ VirtualHandshake-Blogging-SpecialReport.pdf.

21. Wikipeda, the Free Enclyopedia (2005) Retrieved September 25, 2005 from: http://en.wikipedia.org/wiki/Blogging.

22. Wolak, C. (2002). A Model for the Implementation of a Blog in a Manufacturing Environment, Retrieved September 23, 2005 from: http:// www.scisstudyguides.addr.com/papers/cwPrelim inaryDissertationProposal.pdf.

23. Ziegler, D. (2005). Corporations Entering World of Blogs, Retrieved September 14, 2005 from: http://www.technewsworld.com/story/43576.htm 1 